\title{
Anatomical and histological characteristics of teeth in agouti (Dasyprocta prymnolopha Wagler, 1831) ${ }^{1}$
}

\author{
Daiane C. Baia da Silva², Nathália C.F. Fagundes ${ }^{2}$, Francisco B. Teixeira ${ }^{2}$, \\ Nelson E.A. da Penha ${ }^{2}$, Luana N. da Silva Santana ${ }^{2}$, Ana Cristina Mendes-Oliveira ${ }^{2}$ \\ and Rafael Rodrigues Lima ${ }^{3 *}$
}

\begin{abstract}
Silva D.C.B., Fagundes N.C.F., Teixeira F.B., Penha N.E.A., Santana L.N.S., Oliveira A.C.M. \& Lima R.R. 2013. Anatomical and histological characteristics of teeth in agouti (Dasyprocta prymnolopha Wagler, 1831). Pesquisa Veterinária Brasileira 33(Supl.1):5157. Laboratório de Biologia Estrutural e Funcional, Instituto de Ciências Biológicas, Universidade Federal do Pará, Rua Augusto Correa 1, Guamá, Belém, PA 66075-900, Brazil. E-mail: rafalima@ufpa.br

The agouti species Dasyprocta prymnolopha (D. prymnolopha) is a medium-sized rodent, diurnal, and characteristic of northeastern Brazil, south of the Amazon. Several studies have been made on these rodents. However, there is a lack of analysis of masticatory system, in particular morphology of the teeth. Thus, this research seeks to describe anatomical and histological aspects of the agouti teeth. For this purpose, we used adult agouti, in which measurements and descriptions of teeth and dental tissues were made. It was observed that the dental arch of D. prymnolopha comprises of twenty teeth, evenly distributed in the upper and lower arch, being inferior teeth larger than their corresponding higher. The incisors are larger, and between the posterior premolars and molars, there is a gradual increase in length in the anterior-posterior arch. In microscopic examination, a prismatic appearance was observed consisting of enamel prisms arranged in different directions, behind the enamel and dentin with standard tubular dentinal tubules with variable diameter and far between, also showing a sinuous path from the inner portion to the junction with more superficial enamel. Morphological analysis of dental tissues showed that an enamel with structural organization adapted to the act of chewing and high impact dentin compatible with standard tubular function resilience and mechanical damping of masticatory forces, as found in larger animals, confirming the understanding of eating habits that define much of its ecological functions within the ecosystem they inhabit.
\end{abstract}

INDEX TERMS: Agouti, tooth, morphology, Dasyprocta prymnolopha.

RESUMO.- [Características anatômicas e histológicas dos dentes na cutia (Dasyprocta prymnolopha Wagler, 1831).] A cutia espécie Dasyprocta prymnolopha (D. prymnolopha) é um roedor de tamanho médio, diurno e característico do Nordeste do Brasil, sul da Amazônia. Vários estudos têm sido feitos sobre estes roedores. No entanto,

\footnotetext{
${ }^{1}$ Received on July 29, 2013.

Accepted for publication on November 27, 2013.

${ }^{2}$ Instituto de Ciências Biológicas, Universidade Federal do Pará (UFPA), Belém, PA, Brazil.

${ }^{3}$ Laboratório de Biologia Estrutural e Funcional, Instituto de Ciências Biológicas, UFPA, Rua Augusto Correa 1, Guamá, Belém, PA 66075-900, Brazil.*Corresponding author: rafalima@ufpa.br, rafaelrodrigueslima@ hotmail.com
}

há uma carência de estudos do sistema estomatognático, em particular, a morfologia dos dentes. Assim, esta pesquisa procura descrever aspectos anatômicos e histológicos dos dentes cutia. Para isto, nós utilizamos cutias adultas, em que as mensurações e as descrições dos dentes e dos tecidos dentais foram feitas. Observou-se que a arcada dentária de D. prymnolopha é composta por vinte dentes, distribuídas uniformemente no arco superior e inferior, sendo os dentes inferiores, maiores do que os seus correspondentes superiores. Os incisivos são maiores, e entre os pré-molares e molares posteriores, existe um aumento gradual no comprimento do arco anterior-posterior. No exame microscópico, uma forma prismática foi observada o que consiste de prismas de esmalte dispostos em diferentes 
direções, atrás do esmalte e dentina com túbulos dentinários com padrão tubular de diâmetro variável e distantes entre si, mostrando também um caminho sinuoso a partir da parte interna da junção com o esmalte mais superficial. A análise morfológica dos tecidos dentários mostrou um esmalte com a organização estrutural adaptada para o ato de mastigar e dentina de alto impacto compatível com a função do padrão tubular de resiliência e amortecimento mecânico de forças mastigatórias, como encontrado em animais maiores, confirmando o entendimento de hábitos alimentares que definem muito das suas funções ecológicas dentro do ecossistema em que vivem.

TERMOS DE INDEXAÇÃO: Cutia, dente, morfologia, Dasyprocta prymnolopha.

\section{INTRODUCTION}

The agouti species Dasyprocta prymnolopha (D. prymnolo$p h a$ ) is a mammal of the order Rodentia endemic to South America (Eisenberg \& Redford 1999, Hosken \& Silveira 2001). This beast is a medium-sized terrestrial and burrowing rodent (about ten times as heavy as the rat); an adult can weigh of 1400-8500g (Ximenes 1999). This phenotype has a coat with reddish flanks with a contrasting black rump (Bonvicino \& Oliveira 2006, Lee et al. 2006), their legs are long and slender, with the larger and later adapted to run (Tirira 1999, Lange 2003).

The genus Dasyprocta has a wide geographical distribution and occurs in virtually all biomes. This genus inhabits the upland and floodplain forests, open areas of cerrado (vasttropicalsavannaecoregionofBrazil) and caatinga (is a type of vegetation, and anecoregioncharacterized by this vegetation in the northeastern part of Brazil), and is associated with streams. This species occurs preferably in northeastern Brazil, south of the Amazon (Eisenberg \& Redford 1999). The type locality of this species is Belém, capital of Pará.

These animals are diurnal, principally frugivores that not only consume fruit (pulp and seeds), but also leaves, fibers, flowers, and even invertebrates in smaller quanties, usually manipulating seeds with high dexterity with their forelimbs (Henry 1999). The animals of this genus are able to open hard inner layer of the pericarp of many fruits (endocarps) sitting on their hind legs and holding the food, breaking or peeling fruit (Henry 1999). These eating behaviors combined with tooth structure typical of these animals characterize their eating habits and define much of their ecological functions within the ecosystem (Mendes-Oliveira et al. 2012).

Like other rodent species, D. prymnolopha presents teeth heterodont, hypsodont, with continuous growth (Eurell \& Frappier 2006). The incisors with apical foramen permanently open and continuously grow in the apical end throughout life. According to Eisenberg \& Redford (1999), the mechanism of this compensatory growth is continuous over the great wear on the teeth during animal development as a result of eating hard foods. The pattern of tooth wear in these rodents is also directly related to their eating habits. The dental formula of the genus Dasyprocta is presented as: incisors $1 / 1$, canines $0 / 0$, premolars $1 / 1$, molars $3 / 3$. The absence of canines and tooth structure, as different patterns of cusps of teeth are directly linked to the type of food species of the order Rodentia (Janis \& Fortelius 1988).

Macroscopic pattern of dentition of medium-sized rodents are described in the literature (Pough et al. 2003, Bonvicino \& Oliveira 2006, Oliveira et al. 2006); however, little information is available on the microscopic pattern (Oliveira et al. 2007). Thus, the objective of this study was to investigate aspects of dental morphology of D. Prymnolopha, both anatomical and histological findings, in order to present a better understanding of the correlation between dental morphology of these animals, the adaptation of these bodies to habits and their functional role in the ecosystem (Mendes-Oliveira et al. 2012).

\section{MATERIALS AND METHODS}

\section{Animals}

For this study, eight adult male agoutis with average body mass of $2.25 \mathrm{~kg}( \pm 0.28 \mathrm{~kg})$ were used, which were obtained from the animal house of the Universidade Federal do Pará. All experimental procedures were performed in accordance with the standards established by the Ethics Committee on Experimental Animals of the Federal University of Pará (CEPAE-UFPA opinion No. BIO001-10). Moreover, other organs of these animals were also used for other investigations conducted in UFPA, which are not the subject of this work.

\section{Perfusion obtaining samples}

Animals were deeply anesthetized with an intramuscular injection of a mixture of ketamine hydrochloride $(90 \mathrm{mg} / \mathrm{kg})$ and xylazine hydrochloride $(10 \mathrm{mg} / \mathrm{kg})$. After extinction of the corneal reflex, animals were perfused transcardially with heparinized $0.9 \%$ saline solution followed by 4\% paraformaldehyde (Sigma Company, USA) in $0.1 \mathrm{M}$ phosphate buffer (PB) (Freire et al. 2008). Their disarticulated jaws were then decapitated and dissected from their skulls and were finally photographed for subsequent descriptions.

\section{Macroscopic analysis of the teeth}

All teeth were removed, cleaned with curettes for removing the periodontal tissue adhering to the roots, were immersed in $1 \%$ sodium hypochlorite ( $\mathrm{NaOCl}$, Sultan Healthcare, Inc., USA) to remove the rest of the organic material for $10 \mathrm{~min}$, and then washed in distilled water in an ultrasonic bath.

Since then, the teeth were measured in their long axes, in the most extreme apical occluded with a digital caliper (Mitutoyo Absolute Digimatic Series 500, accuracy $\pm 0.02 \mathrm{~mm}$, Aurora, IL, USA) and tabulated with mean and standard deviation.

After measurement, the teeth were evaluated for their external and coronary morphology and number of roots.

\section{Microscopic examination of the teeth}

For analysis by light microscopy (LM), the teeth were sectioned in its long axis and the sections obtained were progressively worn with sandpaper of 1200, 1500 and 2000 grit, washed in 1\% $\mathrm{NaOCl}$ for 5 min, immersed in 17\% EDTA (Ethylenediaminetetraacetic acid) (Vista Dental Products, USA) for $3 \mathrm{~min}$ and washed in distilled water in an ultrasonic bath. Then, the sections were dehydrated in absolute alcohol, cleared with xylol, and coverslipped (Santana et al. 2013). The most representative images were obtained using a digital camera (Olympus Evolt E-330, Center Valley, PA, USA) attached to a light microscope (Olympus BX41, Center Valley, PA, USA). 
For scanning electron microscopy (SEM), the samples were used to observe the external faces of the teeth, and the sectioned teeth were used to visualize the internal faces (face sectioning).

All samples prepared for SEM were immersed in a solution containing $1 \% \mathrm{NaOCl}$ for $5 \mathrm{~min}$ so as to remove any remains of organic matter, followed by immersion in ultrasonic bath with distilled water for $30 \mathrm{sec}$. The cleaning process continued with immersion in 17\% EDTA solution for $10 \mathrm{sec}$ to remove residue fragmentation, and again rinsed with distilled water in ultrasonic bath (Santana et al. 2013).

The samples were dehydrated using ethyl alcohol of increasing solutions and dried at room temperature. Next, the samples were mounted, metalized and evaluated in SEM, model LEO-1430 (Zeiss Inc., Thornwood, NY, USA). Digital micrographs of various regions of the teeth were captured under different magnifications.

These processes made it possible to make a detailed description of the morphology of the incisors, premolars and molars of Dasyprocta prymnolopha.

\section{RESULTS}

The dental formula of Dasyprocta prymnolopha was as follows: incisors $1 / 1$, canines $0 / 0$, premolars $1 / 1$, molars $3 / 3$. With this structure, the dental formula for an adult animal was obtained by an arc (Fig.1).

While measuring the tooth length, it was observed that the lower jaw with teeth showed greater axial length compared to their counterparts in the upper arch; the upper incisors ranged from 30.04-30.46mm, while those presented below were of $53.10-56.68 \mathrm{~mm}$, while in other groups, the dental axial length of the remaining teeth ranged from $8.87-11.24 \mathrm{~mm}$ between the upper and lower in the range of $9.80-12.78 \mathrm{~mm}$. The values found for dental elements are shown in Table 1.

The morphology of crown teeth are shown in Table 2. While analyzing the root portion, it was observed that the upper posterior teeth had, on average, four roots. Palatal root exhibited a slight curvature buccally. In contrast, the lower posterior teeth showed two to four roots, where the roots vestibular had a curvature directed towards the inner portion of the mandibular arch towards the lingual area (Table 3 and 4).

LM showed a pattern of tubular dentines with the tubules winding, traversing the entire thickness of the dentin from the pulp cavity to the enamel. The enamel was shown as a compacted surface layer covering the dentin along its entire length, except the incisal edge of incisors and some occlusal regions of the premolars and molars (Fig.2).

The low magnification photomicrographs obtained by SEM showed a prismatic enamel on the tooth surface (Fig.3A,B), and a tubular orthodentine underlying layer of enamel (Fig.3C,D).

The analysis at higher magnification showed a characteristic dentin pattern classified as orthodentine. This structure can be defined as mineralized cloagenous tissue which circle pulp cavity and presents certain morphologic variations on the direction and dentin tubules diameters. These which are coated with a peritubular dentin and immersed in a layer of intertubular dentin (Miles 1967, Baume 1980). This characteristic pattern of dentin is found in all mammals and some reptiles, amphibians and fishes (Miles 1967, Baume 1980) (Fig.3C,D).
The enamel was shown to be organized into individual prismatic rods with an interprismatic layer between the deep portion adjacent to the dentino-enamel junction and the surface layer (Fig.3E,F). The prisms in turn, were clearly individualized by interprismatic enamel, arranged irregularly, and assumed a sinuous waved form (Fig.3E,F).

The occlusal surface of the analyzed elements, dentin were exposed in some regions (Fig.3A). Furthermore, we observed the presence of enamel amid the exposed dentin surrounding deep grooves, suggesting that this finding is not attributable to normal morphology of the tooth, but the consequent physiological wears their eating habits (Fig.1).

\section{DISCUSSION}

The description of the morphology of the teeth on a microscopic scale of Dasyprocta prymnolopha supports the adaptation of this animal for eating hard foods. Although this is a common feature among members of the order Rodentia, agoutis have specific habits and behaviors that enable them to use hard fruits with higher efficiency than other rodents.

Several studies have been done on D. prymnolopha (Lopez et al. 2004, Braz et al. 2006, Bonvicino \& Oliveira 2006). However, few data exist regarding the stomatognatic system of rodents. Therefore, this study sought to describe the anatomical and histological aspects of their teeth.

Agouti (D. prymnolopha), paca (Agouti paca) and mocó (Kerodon rock) present a pair of incisors in general orange color (color is related to the habit of chewing in these animals), no canines, a pair of premolars, and six molars in each jaw (Eisenberg \& Redford 1999, Thomaz et al. 2006). Furthermore, the lower incisors' elements are more pronounced in length, as in paca (Oliveira et al. 2006).

It was observed that the lower arch of teeth showed a greater axial length compared with their counterparts in the upper arch, contrasting data obtained by Oliveira et al. (2006) in their study of paca (Agouti paca). Between the incisors and the pre-molar, a space is found, which is described by Pough et al. (2003) as a diastema.

The incisors had an open apex, a characteristic morphological finding of teeth in the process of root formation or continued growth, as found in other rodent incisors (Pough, Janis and Heiser, 2003; Oliveira et al., 2006). In the occlusal surfaces of the elements, molariforms of Agouti was observed (the same as that found in pacas); the presence of depressions were circumscribed by a layer of enamel, providing the chewing surface a rather uneven look like elements molariformes equine (St Clair 1986, Dyce et al. 1997, Konig et al. 2004).

The organization of dental tissues observed by SEM and LM showed many similarities compared to other mammals previously described in the literature (Forssell-Ahlberg et al. 1975, Kroon et al. 1986, Pough et al. 2003, Oliveira et al. 2006, Santana et al. 2013).

The thickness and enamel prism organization indicated that the species is compatible with dietary patterns and chewing strength developed by animals of this size (Pough et al. 2003, Oliveira et al. 2006). The enamel prisms provide greater mechanical strength and increase in mechanic 

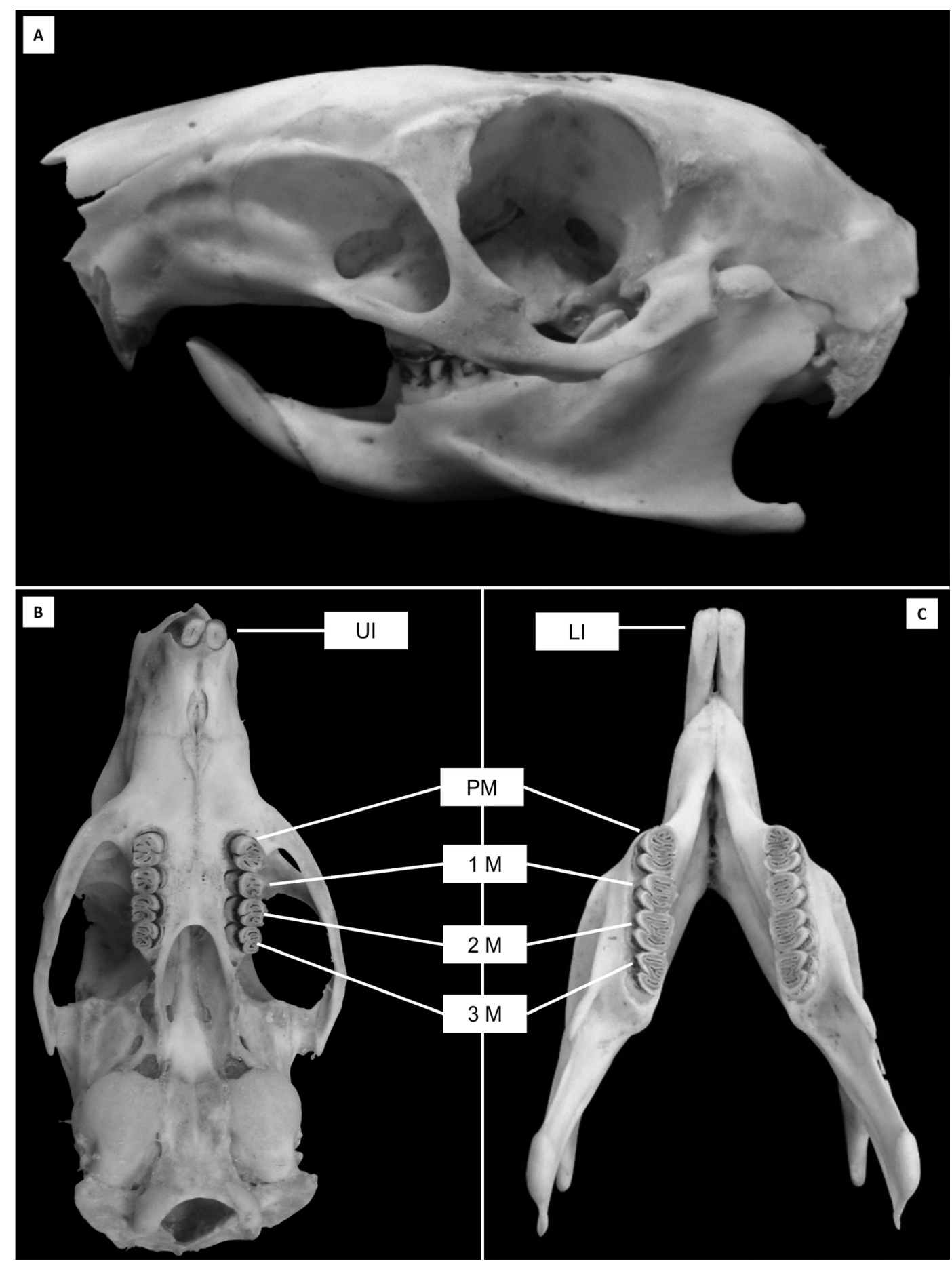

Fig.1. Macrographs skull and jaws of agouti (Dasyprocta prymnolopha). (A) Side view of the skull. (B) Occlusal view of the upper dental arch, (C) Occlusal view of the lower arch. Note the wear of dental structures in their occlusal portion (premolars and molars) and incisal (incisors). Upper incisors (UI), Pre-molars (PM), first molar (1M), second molar (2M), third molar (3M), Lower incisors (LI).

imbrication are more adapted to act as masticatory dental elements, which features a small enamel prismless layer temporary on the tooth surface, or even mice, which have a thin layer of enamel surface (Bishop 1995, Koussoulakou 2009, Ohazama et al. 2010).

The underlying dentin enamel tubules showed a pattern in which the tubules are interleaved by a more compacted dentin, called intertubular dentin, and this pattern is found in other mammals, even in humans (Forssell-Ahlberg et al.
Table 1. Average length of teeth ( $\mathrm{mm})$ : Mean and standard deviation (in the bracket) of the length of the teeth of the species Dasyprocta prymnolopha

\begin{tabular}{lcc}
\hline Teeth & Upper Jaw & Lower Jaw \\
\hline Incisors & $30.25( \pm 0.21)$ & $54.88( \pm 1.78)$ \\
Pre-molar & $8.87( \pm 0.81)$ & $9.80( \pm 1.65)$ \\
$1^{\circ}$ molar & $9.40( \pm 0.96)$ & $10.85( \pm 1.52)$ \\
$2^{\circ}$ molar & $9.37( \pm 0.93)$ & $10.15( \pm 0.52)$ \\
$3^{\circ}$ molar & $11.24( \pm 0.45)$ & $12.78( \pm 0.07)$
\end{tabular}


Table 2. Morphology of the dental crown Dasyprocta prymnolopha

\begin{tabular}{|c|c|c|}
\hline $\begin{array}{l}\text { Teeth } \\
\text { Incisors }\end{array}$ & Upper Jaw Cylindrical & Lower Jaw Cylindrical \\
\hline Pre-molar & $\begin{array}{l}\text { Trapezoidal, being higher in } \\
\text { mesio-distal, with the presence } \\
\text { presence of a deep groove in } \\
\text { the wall palate and vestibular. }\end{array}$ & $\begin{array}{l}\text { Trapezoidal, being greater than } \\
\text { the mesial to distal, with the } \\
\text { presence of a deep groove } \\
\text { in the lingual and buccal wall. }\end{array}$ \\
\hline $1^{\circ}$ molar & $\begin{array}{l}\text { Square, being higher } \\
\text { in mesio-distal. }\end{array}$ & $\begin{array}{l}\text { Trapezoidal, with buccal greater } \\
\text { than the other faces of the } \\
\text { tooth, with the presence of a } \\
\text { deep groove on the buccal wall. }\end{array}$ \\
\hline $2^{\circ}$ molar & $\begin{array}{l}\text { Square, being higher } \\
\text { in mesio-distal, with the } \\
\text { presence of a deep groove } \\
\text { in the wall palate. }\end{array}$ & $\begin{array}{l}\text { Trapezoidal, with buccal greater } \\
\text { than the other faces of the } \\
\text { tooth, with the presence of a } \\
\text { deep groove on the buccal wall. }\end{array}$ \\
\hline $3^{\circ}$ molar & $\begin{array}{l}\text { Square, being higher in } \\
\text { mesio-distal, with the } \\
\text { presence of a deep groove } \\
\text { in the wall palate. }\end{array}$ & $\begin{array}{l}\text { Trapezoidal, with the } \\
\text { presence of a deep groove } \\
\text { on the buccal wall. }\end{array}$ \\
\hline
\end{tabular}

Table 3. Upper Jaw: Morphology of the upper jaw dental root Dasyprocta prymnolopha

\begin{tabular}{|c|c|c|c|}
\hline $\begin{array}{c}\text { Teeth } \\
\text { Incisors }\end{array}$ & $\begin{array}{l}\text { Number } \\
\text { of roots }\end{array}$ & Shape & Direction of root \\
\hline & One & Taper and bulky & Bend to the palate \\
\hline Pre-molar & r Three & $\begin{array}{l}\text { Root is distolingual, thin. Root } \\
\text { is distobuccal, long and curved } \\
\text { to the lingual. Mesial root is } \\
\text { bulky for the buccal groove. }\end{array}$ & $\begin{array}{l}\text { Distobuccal directed to } \\
\text { palatal, and mesial } \\
\text { distolingual arranged } \\
\text { along the axis of the } \\
\text { tooth. }\end{array}$ \\
\hline $1^{\mathrm{o}}$ molar & Three & $\begin{array}{l}\text { Root is long and voluminous } \\
\text { palate, palatal root mesio- } \\
\text { buccal and palatal root of this } \\
\text { smaller volume and size }\end{array}$ & $\begin{array}{l}\text { Palatal root curvature to } \\
\text { the vestibular root mesio- } \\
\text { palatina distopalatina } \\
\text { and arranged along } \\
\text { the axis of the tooth. }\end{array}$ \\
\hline $2^{\mathrm{o}}$ molar & Three & $\begin{array}{l}\text { Root long lingual and buccal } \\
\text { curvature. Mesiopalatina } \\
\text { root and have similar } \\
\text { lengths distopalatina }\end{array}$ & $\begin{array}{l}\text { Palatal root curvature to } \\
\text { the vestibular root mesio- } \\
\text { palatina distopalatina } \\
\text { and arranged along } \\
\text { the axis of the tooth }\end{array}$ \\
\hline $3^{\circ}$ molar & Three & $\begin{array}{l}\text { Lingual root bulky (large) and } \\
\text { long with buckle to school; } \\
\text { mesial buccal root curvature } \\
\text { with conical short buccal and } \\
\text { lingual root of this cone with } \\
\text { diameter smaller than the } \\
\text { mesial vesibular. }\end{array}$ & $\begin{array}{l}\text { Lingual root curvature } \\
\text { buccally; mesial buccal } \\
\text { root straight and } \\
\text { distobuccal root with } \\
\text { a slight curvature in } \\
\text { buccal }\end{array}$ \\
\hline
\end{tabular}

Table 4. Lower Jaw: Morphology of the lower jaw dental root Dasyprocta prymnolopha

\begin{tabular}{|c|c|c|c|}
\hline $\begin{array}{c}\text { Teeth } \\
\text { Incisors }\end{array}$ & $\begin{array}{l}\text { Number } \\
\text { of roots }\end{array}$ & Shape & Direction of root \\
\hline & One & Taper and bulky & Bend lingually \\
\hline Pre-molar & Three & $\begin{array}{l}\text { Distal root bulky and } \\
\text { long. Root mesial } \\
\text { buccal and mesial } \\
\text { lingual bulky and short }\end{array}$ & $\begin{array}{l}\text { Root mesiolingual } \\
\text { inclined lingually. Mesio- } \\
\text { buccal roots and disposed } \\
\text { along the distal } \\
\text { axis of the tooth. }\end{array}$ \\
\hline $1^{\circ}$ molar & Four & $\begin{array}{l}\text { Mesiobuccal root bulkier } \\
\text { than mesiolingual. } \\
\text { Lingual root of this } \\
\text { bigger and bulkier } \\
\text { than the other }\end{array}$ & $\begin{array}{l}\text { Root it with buccal } \\
\text { buccal inclination. } \\
\text { The others are } \\
\text { arranged along the } \\
\text { tooth axis }\end{array}$ \\
\hline $2^{\circ}$ molar & Four & $\begin{array}{l}\text { Distal root bulky and } \\
\text { long. Root mesial buccal } \\
\text { and mesial lingual } \\
\text { bulky and short }\end{array}$ & $\begin{array}{l}\text { Mesial root curvature } \\
\text { for lingual and } \\
\text { distal root straight }\end{array}$ \\
\hline 3o molar & Two & $\begin{array}{l}\text { Mesial root tapered distal } \\
\text { bulky. Root bit long } \\
\text { and has a flattening } \\
\text { in the mesio-distal }\end{array}$ & $\begin{array}{l}\text { Mesial root curvature } \\
\text { for lingual and } \\
\text { distal root straight }\end{array}$ \\
\hline
\end{tabular}

1975, Brännström \& Garberoglio 1972, Muylle et al. 2001). This tubular structure, filled with fluid and collagenous materials found in several species reported in the literature, confer resilience and cushioning to the impacts applied on the enamel (Forssell-Ahlberg et al. 1975, Brännström \& Garberoglio 1972, Muylle et al. 2001). In this research, our methodology did not allow SEM observation to look inside these tubules, but the findings suggest the same internal organization as found in other animals (Forssell-Ahlberg et al. 1975, Brännström \& Garberoglio 1972, Muylle et al. 2001).

The tubular pattern found with individual tubules is characteristic of a pattern of dentin termed orthodentine found in the dentin of some mammals, as depicted through Santana et al. (2013). Unlike other types of dentin such as vasodentina, this dentin has some morphological variations with respect to the direction of the dentinal tubules (sometimes it can present itself very much branched or deformed in some species), the most common among mammals.

The findings from LM and SEM revealed that the tubules showed a direction between the root canal pulp cavity to the surface with enamel cementum, which assumes a per-

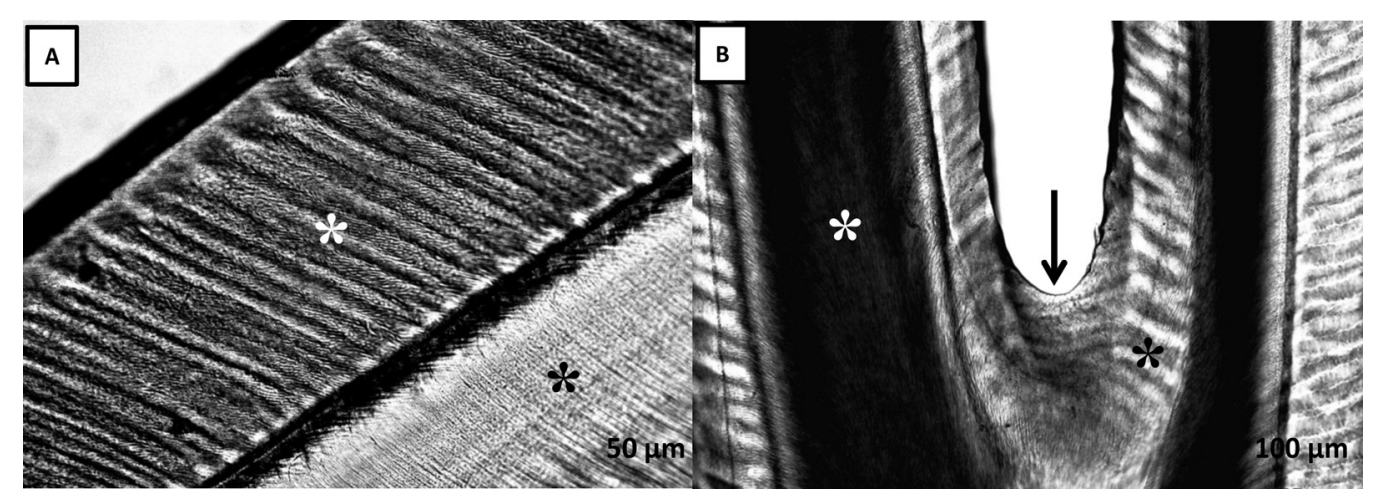

Fig.2. Light microscopy of the enamel and dentin of the agouti (Dasyprocta prymnolopha). (A) Signaling in enamel (white asterisk) and dentin (black asterisk). (B) Black asterisk indicates enamel and white asterisk indicates dentin. Arrow indicates the bottom of a sulcus occlusal. 


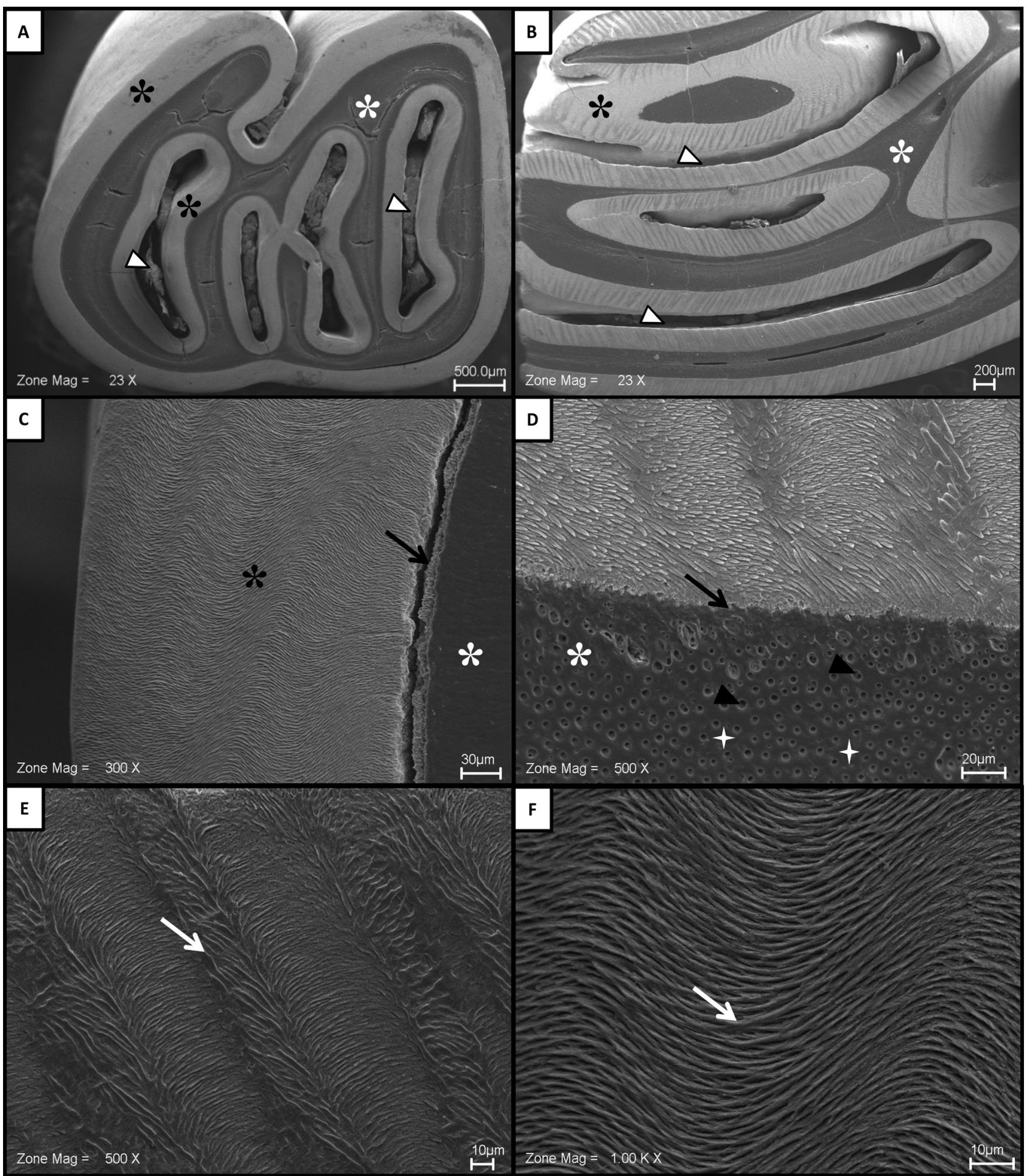

Fig.3. Scanning electron microscopy of enamel and dentin of the agouti (Dasyprocta prymnolopha). (A) Occlusal view of a molar with enamel surface (black asterisk) bypassing the dentin (white asterisk). Arrow heads indicate grooves occlusal enamel coated. (B) Sample worn along a molar, where you can see the layout of the enamel (black asterisk), dentin (white asterisk) and blind grooves (arrow heads). (C,D) Black asterisk indicates enamel, white asterisk indicates dentin, arrow indicates dentino-enamel junction, arrow heads indicate dentinal tubules and crucifix in intertubular dentin. (E,F) Arrows indicate arrangement of enamel prisms.

meable fabric and an important means of communication with the pulp tissue as described in humans and other animals (Brännström \& Garberoglio 1972, Vongsavan \& Matthews 1991, Muylle et al. 2001, Robb et al. 2007).

Thus, the dental morphology found in Dasyprocta prym- nolopha reflects the masticatory function in which the incisors show tissue resistance to allow biting hard surfaces, and also the remaining teeth with a tissue structure adapted to a grinding masticatory act of high impact, complementary to the act of biting. 


\section{REFERENCES}

Baume L.J. 1980. The biology of pulp and dentine (Monogr.). Oral Sci., Basel, 8:1-183.

Bishop M.A. 1995. Is rabbit dentine innervated? A fine-structural study of the pulpal innervation in the cheek teeth of the rabbit. J. Anat. 186:365372.

Brannstrom M. \& Garberoglio R. 1972. The dentinal tubules and the odontoblast process. Acta. Odontol. Scand. 30:291-311.

Braz D.C., Pinheiro A.M.V., Moura W.L. \& Carvalho M.A. 2006. Descrição histológica dos incisivos da cutia Dasyprocta prymnolopha (Wagler, 1831). Ciênc. Anim. Bras. 7:177-185.

Dyce K.M., Sack W.O. \& Wensing C.J.G. 1997. Tratado de Anatomia Veterinária. Guanabara Koogan, Rio de Janeiro, 872p.

Eisenberg J.F. \& Redford K.H. 1999.Mammals of the Neotropics - The Central Neotropics: Ecuador, Peru, Bolivia, Brazil.Univ. Chicago Press, Chicago. 624.

Eurell J.A. \& Frappier B.L. 2006. Dellmann's Textbook of Veterinary Histology. $6^{\text {th }}$ ed. Blackwell Publishing, Ames, IA. 416p.

Forssell-Ahlberg K., Brannstrom M. \& Edwall L. 1975. The Diameter and number of dentinal tubules in rat, cat, dog and monkey: a comparative scanning electron microscopic study. Acta. Odontol. Scand. 33:243250.

Freire M.A.M., Tourinhoc S.C., Guimarães J.S., Oliveira J.L.F., Picanço-Diniz C.W., Gomes-Leal W. \& Pereira Jr A. 2008. Histochemical characterization, distribution and morphometric analysis of NADPH diaphorase neurons in the spinal cord of the agouti. Front. Neuroanat. 2:2-9.

Henry O. 1999. Frugivory and the importance of seeds in the diet of the orange-rumped agouti (Dasyprocta leporina) in French Guiana. J. Trop. Ecol. 15:291-300.

Hosken F.M. \& Silveira A.C. 2001. Criação de Cutias. Aprenda Fácil Editora, Viçosa, MG.

König H.E., Sautet J. \& Liebich H.G. 2004: Anatomia dos Animais Domésticos. $4^{\text {a }}$ ed. Artmed, Porto Alegre. 787p.

Koussoulakou D.S., Margarits L.H. \& Koussoulakos I. 2009. A Curriculum vitae of teeth: evolution, generation, regeneration. Int. J. Biol. Sci. 5:226243.

Kroon J., Grossman E.S. \& Cleaton-Jones P. 1986. A scanning electron microscope study of dentinal tubule continuity in monkey tooth sections. Endod. Dent. Traumatol. 2:39-42.

Lange R.R., Abilhôa V., Margarido T.C.C. \& Monteiro-Filho E.L.A. 2003. Relação entre peso e comprimento total em ninhadas de Dasyprocta azarae Lichtenstein, 1823 em cativeiro. Arq. Ciênc. Vet. Zool. Unipar 6:101-104.

Lee T.E., Hartline-Jr H.B. \& Barnes B.M. 2006. Mammalian species (Dasyprocta ruatanica). American Society of Mammalogists 800:1-3.

Lopes J.B., Cavalcante R.R., Almeida M.M., Carvalho M.A.M., Moura S.G., Filho L.A.D. \& Conceição W.L.F. 2004. Desempenho de cutias (Dasyprocta prymnolopha) criadas em cativeiro do nascimento até o desmame em Teresina, Piauí. Revta Bras. Zootec. 6:2318-2322.

Mendes-Oliveira A.C., Santos P.G.P., Carvalho Júnior O., Lima R.S., Montag L.F.A., Maria S.L. \& Rossi R.V. 2012. Edge effects and the impact of wildfires on populations of small non-volant mammals in the forest-savanna transition zone in Southern Amazonia. Biota Neotrop. 12:12-29.

Miles A.E.W. 1967. Structural and Chemical Organization of Teeth. Academic Press, New York.

Muylle S., Simoens P. \& Lauwers H. 2001. The distribution of intratubular dentine in equine incisors: a scanning electron microscopic study. Equine Vet. J. 33:65-69.

Oliveira F.S., Canola J.C., Oliveira P.T., Pecora J.D. \& Capelli A. 2006. Anatomoradiographic description of the teeth of pacas bred in captivity (Agouti paca Linnaeus, 1766). Anat. Histol. Embryol. 35:316-318.

Oliveira F.S., Canola J.C., Oliveira P.T., Pecora J.D. \& Capelli A. 2007. Microscopic characterization of teeth of pacas bred in captivity (Agouti paca, Linnaeus, 1766). Anat. Histol. Embryol. 36:371-374.

Oliveira J.A. \& Bonvicino C.R. 2006. Ordem Rodentia, p. 351-411. In: Reis N.R., Peracchi A.L., Pedro W.A. \& Lima I.P. (Eds), Mamíferos do Brasil. Edifurb, Londrina.

Ohazama A., Blackburn J., Porntaveetus T., Otab M.S., Choic H.Y. \& Johnson E.B. 2010. A role for suppressed incisor cuspal morphogenesis in the evolution of mammalian heterodont dentition. Proc. Natl Acad. Sci. USA 107:92-97.

Pough F.H., Janis C.M. \& Heiser J.B. 2003. A Vida dos Vertebrados. 4aㅡ ed. Atheneu Editora, São Paulo. 750p.

Robb L., Marx J., Steenkamp G., Van Heerden W.F., Pretorius E. \& Boy S.C. 2007. Scanning electron microscopic study of the dentinal tubules in dog canine teeth. J. Vet. Dent. 24:86-89.

Santana L.N.S., Barbosa L.V.M., Teixeira F.B., Costa A.M.P., Fernandes L.M.P. \& Lima R.R. 2013. Morphology of the Dentin Structure of Sloths Bradypus tridactylus: a light and scanning electron microscopy investigation. Anat. Histol. Embryol. 14. Doi: 10.1111/ahe.12029. [Epub ahead of print]

St Clair L.E. 1986. Anatomia dos Animais Domésticos. Guanabara Koogan, Rio de Janeiro. 324p.

Thomaz J.M., Carvalho A., Miglino M.A., Maçanares C.A.F., Ambrósio C.E. \& Oliveira M.F. 2006. Teeth morphologic characterization of rock cavyKerodon rupestris: Mammalia: Rodentia. Braz. J. Vet. Res. Anim. Sci. 43:702-707.

Tirira D.S. 1999. Mamíferos del Ecuador. Museo de Zoologia, Centro de Biodiversidade y Ambiente, Ponitificia Universidade Católica del Equador, Sociedad para la Investigación y Monitoreo de la Biodiversidae, Quito. 245p.

Vongsavan N. \& Matthews B. 1991. The permeability ofcatdentine in vivo and in vitro. Arch. Oral Biol. 36:641-646.

Ximenes G.E.I. 1999. Sistemática da Família Dasyproctidae Bonaparte, 1838 (Rodentia, Histricognathi) no Brasil. Universidade de São Paulo, São Paulo. 245p. 